\title{
Communication for coproduction: a systematic review and research agenda
}

\section{Huafang Li}

To cite this article: Huafang Li (2019): Communication for coproduction: a systematic review and research agenda, Journal of Chinese Governance, DOI: 10.1080/23812346.2019.1695711

To link to this article: https://doi.org/10.1080/23812346.2019.1695711

曲 Published online: 29 Nov 2019.

Submit your article to this journal $\pi$

Q View related articles $₫$

View Crossmark data \lceil 


\section{Communication for coproduction: a systematic review and research agenda}

\section{Huafang Li}

School of Public, Nonprofit, and Health Administration, Grand Valley State University, Grand Rapids, MI, USA

\begin{abstract}
Government and nonprofit organizations communicate with the public to reduce the degree of information asymmetry that could impede the two parties from working together to achieve higher levels of performance and accountability and coproduce better policy outcomes and public goods. Different organizational communication strategies' influences, including choices of information channels, types, frequency, and contents, vary across individuals. This study reviews the relevant literature, discusses various communication strategies and their influences on citizens and implications for public policies and programs, develops a conceptual framework, and proposes a research agenda for future studies.
\end{abstract}

\section{ARTICLE HISTORY}

Received 12 May 2019

Accepted 17 November 2019

\section{KEYWORDS}

Coproduction; communication; information; nonprofit; donation

\section{Introduction}

Efficient, effective, and equitable governance depends on public organizations and individuals working together to coproduce desirable policy outcomes and public goods. ${ }^{1}$ Coproduction is '... the critical mix of activities that service agents and citizens contribute to the provision of public services'.2 Governments and nonprofits want citizens to participate in a wide range of public services to deliver them effectively. Coproduction occurs in various policy areas and public service sectors, such as childcare, law enforcement, education, emergency responses, environment, immigration, infrastructure, public safety, health, and many others, ${ }^{3}$ and its importance in democratic governance has attracted considerable amount of scholarly attention. ${ }^{4}$ However, the answer to the question, 'How can the goals of coproduced services be achieved most successfully?' remains unclear.

The existing literature has studied the definition and typology of coproduction, explored examples of it in different public service areas across the world, and investigated the influences of coproducers' characteristics. Many have focused on the way individual and organizational characteristics influenced the coproduction of public services. For example, people with more education are more aware of social needs and are able to participate in coproduction better, while such organizational factors as 
administrators' attitude, institutional structure, and organizational culture, all influence coproduction in various ways. Clearly, these influential factors have important practical implications for coproduction. ${ }^{5}$

However, most of the existing literature has seemed to assume that the information public organizations and citizens exchange during the coproduction process is symmetric. For example, when scholars have argued that individuals' educational levels were associated positively with their engagement in the coproduction of K-12 education, they assumed that these individuals had information about the schools' needs, students' conditions, and the ways to improve learning outcomes and were able to make the best coproduction decisions based on such information. They also assumed that schools knew how to reach these individuals effectively and communicate information to different types of individuals with heterogeneous information preferences. However, in reality, individuals often are unaware of the coproduction needs and opportunities, and the ways to coproduce successfully, and organizations are unable to deliver the message to the targeted audience effectively because of the information asymmetry between the two parties. Unfortunately, very few studies have focused on the information asymmetry between organizations and citizens and its influences on coproduction. $^{6}$

Information asymmetries exist commonly between public organizations and individual citizens and influence coproduction adversely. For example, when nonprofit healthcare providers serve as government contractors, there are two information asymmetries: first, that between the government and the nonprofit contractors who provide healthcare services, and that between the nonprofit service providers and clients with respect to health services' quality. These information asymmetries can foster distrust and reduce healthcare services' efficiency thereby. ${ }^{7}$ Another example is the asymmetric information between nonprofit organizations and donors. Generally, nonprofits are less aware of their donors' information preferences, and knowing their donors better and motivating them to cofinance social goods with donations always is challenging for them. ${ }^{8}$ Therefore, unless information asymmetries are taken into consideration, it is unlikely that public organizations and individuals will coproduce effectively.

Communications among public organizations and citizens play a critical role in reducing the degree of information asymmetry and ensuring successful coproduction. Graber stated that 'A well-functioning modern democracy requires that bureaucrats listen sympathetically and respectfully to citizens and vice versa'. ${ }^{9}$ However, effective communication is necessary to maintain a healthy relationship and build mutual trust that facilitates coproduction.

Thus, how can public organizations communicate with citizens effectively to facilitate coproduction and achieve better outcomes? This study reviews the relevant literature and conceptualizes the communication process between public organizations and citizens. To conduct the systematic review, we used the Preferred Reporting Items for Systematic Reviews and Meta-Analyses (PRISRMA) method. ${ }^{10}$ We first searched the keywords 'coproduction/coproduce/co-creation/co-provision' in titles, keywords, and abstracts of papers published in the Google Scholar database, which is more inclusive than are other databases (e.g., Web of Science), and identified 9720 articles. Then we 
followed Li and Van Ryzin and limited our search to journals in the public policy and administration field (Appendix) by excluding non-public administration journals, such as BMJ, Journal of Biological Chemistry, and Proceedings of the International Conference of the European Academy of Design, and found 117 articles dated from 1987 to 2019. ${ }^{11}$ We used these papers to build the initial dataset for the systematic review. Then, after reading each paper carefully, we excluded those that were unrelated to information communication between the public organizations and individual coproducers, and included 37 papers in the final analysis (Figure 1).

In addition, we also included relevant studies based on our reading that reflect our own viewpoint. We admit that the limitations of our reading experience could bias the analysis and therefore, the results should not be interpreted without caution, as indicated in the discussion part. Thereafter, various organizational communication strategies and their influences on citizens and implications for coproducing public policies and programs' outcomes are documented. The study also develops a conceptual framework and concludes with a research agenda for future studies.

\section{What is coproduction?}

Coproduction is a process that is too complex to result in consensus about its definition. In this study, 'coproduction' refers to the critical mix of activities in which public

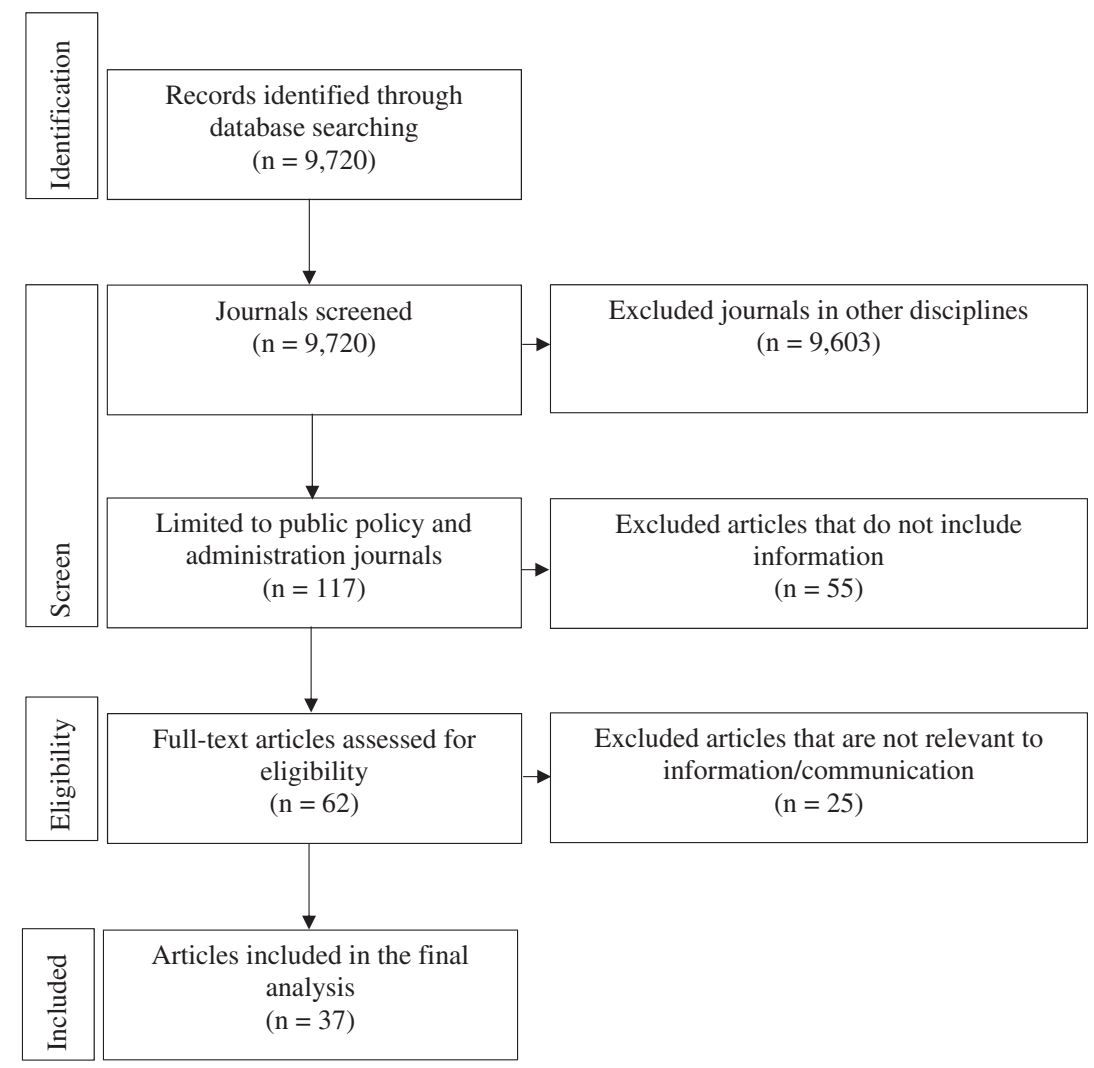

Figure 1. The PRISMA flow for the systematic review. 
organizations, citizens, groups, and communities work together to provide public goods and services. ${ }^{12}$ Further, donating to nonprofits also is a critical form of coprovision of goods and services to meet social needs. It should be noted that nonprofit organizations played two roles in the coproduction process. On the one hand, as many have studied already, nonprofits coproduce services with government agencies; $^{13}$ on the other hand, nonprofits, particularly those that rely primarily on donations to function, are public organizations and try to motivate individuals to donate time and money to produce services. ${ }^{14}$ Ferris stated that:

Nonprofit organizations oftentimes provide goods and services which are close substitutes for publicly provided goods and services. These organizations are often the recipient of citizens' time and/or money donations. Thus, the nonprofit organization can be perceived as a conduit for

the coprovision activities of individual citizens. The coprovision activities of individuals via the nonprofit organization enhance the resources at the disposal of the public sector. To the extent that nonprofit organizations can marshal donations of money and human resources by individuals, the public sector is able to ensure continued service delivery levels with diminished government revenues or expanded service delivery levels with a constant level of government revenues. ${ }^{15}$

It is important to realize the fact that nonprofits can be contractors and partners of, and competitors with government agencies in delivering public services. ${ }^{16}$ As Ferris pointed out, 'the importance of the nonprofit sector substituting for the public sector as a provider ... is of special significance due to liberalization of provisions in recent tax legislation permitting the deduction of charitable money contributions'. ${ }^{17}$ When nonprofits and government agencies provide the same or complementary services, both need to motivate citizens to coproduce desirable outcomes. Even some membership-based nonprofits, such as alumni associations, also need to motivate alumni to give back to coproduce services that benefit their alma mater, association, and alumni. ${ }^{18}$ Thus, we also included donations as a special form of coproduction.

Coproduction increases both the quality and quantity of public goods and services provided, and is critical to public organizations' legitimacy, democratic governance, and modern welfare states' development and sustainability. ${ }^{19}$ For example, city governments rely on citizens to cooperate in recycling to maintain a clean environment, ${ }^{20}$ educational institutions depend on students to engage in the learning process, ${ }^{21}$ and nonprofits solicit individuals to donate and volunteer to support their missions. ${ }^{22}$ Together, they all coproduce goods and services to meet social needs.

There are multiple facets, stages, and types of coproduction across different public service areas. $^{23}$ In a recent review, based on their investigation of who is involved in coproduction, when in the service cycle it occurs, and what is generated in the process, Nabatchi, Sancino, and Sicilia developed a typology of coproduction that includes three levels (individual, group, collective) and four phases (commissioning, designing, delivering, assessment). ${ }^{24}$ An example of the co-delivery phase at the individual level could be 'A doctor and patient work together to implement dietary, exercise, smoking cessation, or other activities to meet health needs'; at the group level, an example could be 'School officials and teachers work with a group of parents who have children with special needs to provide in-class and extra-curricular educational activities', 
and at the collective level, an example could be 'A local parks department works with citizens to construct and maintain bicycle routes throughout the community'. ${ }^{25}$

Voorberg, Bekkers, and Tummers reviewed 122 articles and books on co-creation or coproduction published between 1987 and 2013 and summarized coproduction's objectives, influential factors, and outcomes. According to their analyses, coproduction's objectives include being more effective and efficient, providing greater customer satisfaction, and increasing citizen participation and involvement. Further, both citizens' characteristics, such as intrinsic values, skills, and sociodemographic and organizational factors, such as compatibility with citizen participation, open attitude, and organizational incentives, influence the coproduction process. Outcomes include increasing effectiveness, efficiency, enhancing citizens' satisfaction and involvement, strengthening social cohesion, and democratizing public services. ${ }^{26}$

\section{Communication matters in coproduction}

All of these different facets, stages, types, levels, objectives, outcomes, and influential factors suggest a complex relationship between public organizations and their employees and citizens during the coproduction process. For example, the US Social Security Administration (SSA) is in contact with more than 47 million citizens, receives 60 million telephone calls, and operates 1300 field offices to which citizens have access. $^{27}$ Without effective communication and exchange of information, the SSA would be very unlikely to serve the people well. Frontline public servants, such as police officers, teachers, and counselors, interact with citizens on a daily basis, and rely heavily on their cooperation and compliance to do their jobs well, which also requires effective communication. ${ }^{28}$ In summary, better coproduction requires more effective communication.

Very few existing studies of coproduction have investigated information communication between public organizations and citizens. ${ }^{29}$ Most of the existing literature on communication has focused on within- or inter-organizational communication and has found evidence that ineffective communication hinders organizational performance and intergovernmental collaborations. ${ }^{30}$ However, relatively little attention has been paid to communication's role in the coproduction process. Whether citizens serve individually or collectively as the initiators, co-designers, or co-implementers to commission, design, deliver, and assess coproduction, information between the two parties is assumed to be symmetric-you know what I know and we both know that. If this is the case, it will be less difficult for the two parties to work together across different levels and phases to coproduce better outcomes.

However, in reality, there is an information asymmetry problem-governments and nonprofits usually are less informed about individuals' heterogeneous information preferences for policies and public goods and services. ${ }^{31}$ This asymmetric information between public organizations and individuals is a significant barrier to the effective coproduction of better policy outcomes and public goods. For example, information asymmetry discourages patients from seeking healthcare professionals' help. ${ }^{32}$ Further, in the absence of symmetric information and mutual understanding, decision makers have not used scholarly public policy analyses to coproduce better policies and 


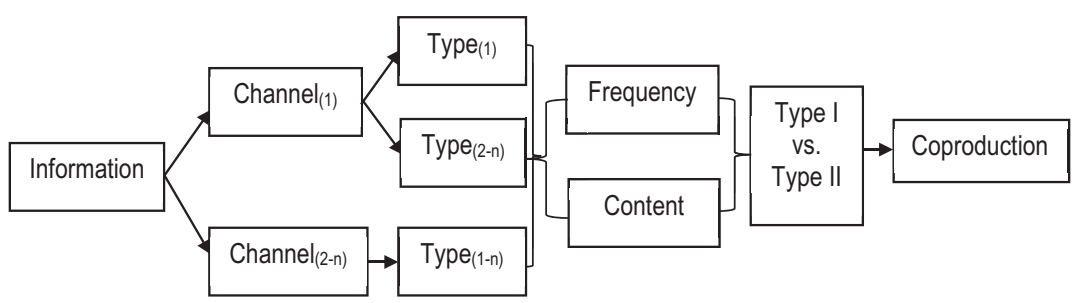

Figure 2. Conceptual research framework of communication for coproduction.

projects. $^{33}$ Effective communication can reduce the degree of information asymmetry and thus help improve the coproduction.

Based on the classic conception of the communication process ${ }^{34}$ and the new developments in public and nonprofit communications, ${ }^{35}$ we propose a novel conceptual framework to study the public communication process and its effects on coproduction. Lasswell identified five major communication elements: sources, messages, channels, receivers, and effects. ${ }^{36}$ Here, public organizations are the information sources, or senders. In this study, we began our analysis by focusing on one public organization's communication with citizens. Thus, we do not discuss the situation in which there are multiple public organizations. Different citizens are the information receivers who obtain various messages from different information channels that affect their coproduction decisions and behavior. Lasswell did not discuss the way the frequency or amount of information influences the outcomes intended. Graber noticed the effects of information noises and redundancies, which are related closely to the information frequencies that Li discussed. Li also discussed the influence of information types and contents, which Lasswell and Graber referred to as messages. ${ }^{37}$ Building on the previous discussion, we proposed the following conceptual framework for further analyses (Figure 2).

This study's objective was to provide a preliminary answer to the question, how can public and nonprofit organizations communicate various types, frequencies, and contents of information through varied information channels to different types of citizens to achieve effective communications that enhance coproduction?

In the following sections, we highlight studies on communication between public organizations and individual citizens to contextualize our study of the effects of such communication on various forms of coproduction. First, we discuss information channels' influence on coproduction, then explore the way different types, frequencies, and contents of information affect different citizens and their implications for coproduction.

\section{Information channels}

Public organizations can use various information channels, including online and offline, to communicate with individual citizens to motivate them to coproduce. However, communication's effects on coproduction vary across different information channels. Graber discussed typical advantages and disadvantages of a variety of informational channels: wire services, newspapers, magazines, radio, television, websites, direct mails, videotapes, billboards, and posters. Channels vary in cost, flexibility, and ability to 
personalize contents. For example, many government agencies use recorded telephone messages not only to take advantage of their low cost and continual access, but also to provide multilingual versions. However, they lack the personal contact that may be essential for effective communication. In addition, news briefings different media outlets provide may be able to deliver the principal information timely. However, mass media might be unable to supply the details about complex issues recipients need. ${ }^{38}$

The growing use of online communication channels has changed the way public services are delivered and citizens' reactions. In particular, social media and mobile devices channel information flow in a way that allows immediate communications. A recent study, however, documented information and communication technology's (ICT) evolution in public administration and concluded that citizens' massive access to ICT channels through which public organizations can communicate with them instantly does not ensure their satisfaction with public services. ${ }^{39}$ Theoretically, online channels either can be used to facilitate communications and encourage coproduction or to bypass interactions with citizens and discourage it. ${ }^{40}$ Very few studies have examined ICT or new media's effects on citizens' coproduction decisions. Meijer argued that digital platforms allow citizens to form online communities to coproduce public services, as such communities foster both the exchange of experiential information and socioemotional support. ${ }^{41}$ Ingrams studied the way mobile phones' use has transformed civic participation. For example, in Africa, using mobile phones increased civic engagement activities, such as contacting government offices to report an issue. ${ }^{42}$ Another study in the Netherlands showed when the police used new media, it strengthened the coproduction of public safety because the new media allowed them to reach more citizens $24 / 7$ without incurring a high cost. ${ }^{43}$

Proposition 1: Using ICT to obtain information increases citizen coproduction.

Among information channels, such as accrediting agencies, the media, online platforms, 'word of mouth', and past personal experiences with nonprofits, Li and McDougle used individual-level data from an original survey of residents in San Diego County, California to examine such information channels' effects on people's charitable giving and volunteer decisions. They found that personal experiences with nonprofits were one of the most salient information channels that influenced individuals' decisions both to give money and volunteer their time to coproduce social goods. ${ }^{44}$ In a series of follow-up studies on experiential philanthropy courses that offer students opportunities to experience philanthropic giving through a service learning approach, they confirmed that the 'learning by giving' experience increased students' awareness of social needs and nonprofit organizations' roles, and their intentions to coproduce philanthropic outcomes by volunteering and donating in the future. ${ }^{45}$ Citizens' experiences with Urban Living Labs, which are public spaces where local authorities engage citizens to develop innovative urban services, could encourage them to learn more about the policy issues and become involved in service delivery. ${ }^{46}$ Although there are challenges, when both practitioners and scholars interact with each other and experience other's shoes, they will be more likely to contribute to coproduction. ${ }^{47}$

Proposition 2: Learning from experience increases citizen coproduction. 


\section{Information types}

In general, if more pieces of information and knowledge are exchanged between public organizations and citizens, they are more likely to coproduce better outcomes. For example, when governments provided immigrant parents with knowledge useful to their children's language development, such knowledge of coproduction had a positive impact on the learning outcomes of immigrant children, especially, disadvantaged ones. ${ }^{48}$

Various scholars have categorized information differently, and unfortunately, there is no consensus on the subject. Some information types are very detailed, while others are defined more broadly. For example, Stevens and McGowan suggested that information could be divided into different types based on organizations' different managerial levels. For example, at the organizational or institutional level, 'statutory authority, charter, long-term economic and budget resources, forecasting information on political uncertainty, social and technological trends' are the types of information needed for strategic planning. At the management level, 'control objectives, resources available, long-term needs, operational capability, resource potential' are the information needed for mid-level management or coordination. At the operational task level, 'task technology, process requirements, resource availability, performance data, financial support, standards development, service impact' are those needed for supervision. ${ }^{49}$ Although their categorization of information types was sophisticated, it is very difficult to distinguish organizational information from information generated outside the organization based on their categorization.

Our foci here were the different types of information organizations produce. Hyndman provided a list of nonprofit organizational information: goals; objectives; officers; outputs; efficiency; administration costs; simplified operating statements and balance sheets; audited operating statements, balance sheets, and funds flow statements; future objectives, budget information, and so on. He found that donors ranked organizational goals, problems (social needs), administrative costs, output, and efficiency as their top five types of information needs. ${ }^{50}$ However, unless a study is interested in a particular type of information, Hyndman's categorization would be too complex to be useful. For example, ordinary citizens are unlikely to be able to distinguish between a simplified and audited balance sheet. They also are unlikely to use that information printed in those sheets to inform their coproduction decisions-whether or not to donate money and time to nonprofit organizations. Scholars group detailed organizational information into various types, and financial and nonfinancial information are the two used most commonly. ${ }^{51}$

$\mathrm{Li}$ argued that the types of information above either are too detailed and complex or too abstract and simplified. Accordingly, he proposed five different information types: (1) basic information, such as organization name, location, leadership, and age; (2) mission-related information, such as mission, social causes related to it, values that mission, goals, and program objectives reflect; (3) financial information, such as income, revenue sources, expenses, investments, administrative costs, and information on balance sheets; (4) performance information, such as outcomes, citizens' trust and satisfaction, and ratings from independent agencies, and (5) direct requests for coproduction. For example, a nonprofit organization can request donations without 
presenting any information but the organization's name. Li's five information types cover a wide range of organizational information in sufficient detail. Furthermore, $\mathrm{Li}$ argued that, except for the basic information that organizations must produce and disclose, all other types can be communicated with stakeholders and the public strategically to achieve desirable outcomes. ${ }^{52}$ To review different information types' effects on coproduction, we paid particular attention to experimental studies, because these provide evidence of causal relations and are being used increasingly in the public administration and nonprofit management areas. ${ }^{53}$

Mission related information. Mission reflects the organization's values, signals legitimacy, and provides guidelines for the public, and thus influences coproduction outcomes. For example, public organizations' representativeness, a core value of social equity, can increase citizens' willingness to coproduce better policy outcomes. This is because the same or similar social identity or cultural homophily eases the communication burden between public servants and citizens and makes it easier to transmit effective informational messages and contents. As Graber argued, 'A Hispanic public health nurse, for example, may find it easier to advise Hispanic women about maternal health issues than a nurse drawn from a different ethnic group. Effectiveness also suffers if there are distortions in messages, delays in transmission, or various transmission channels are obstructed or unavailable'.54 Although representativeness' effects vary across different public organizations, in general, it provides an advantage that enhances coproduction and democracy. ${ }^{55}$ Riccucci and colleagues documented the causal relation between representation and coproduction in a series of experimental studies. ${ }^{56}$ For example, Riccucci, Van Ryzin, and Li found that increasing female representation in a recycling policy initiative also increased female citizens' willingness to recycle hard plastics, and engage in light and hard composting significantly. ${ }^{57}$

Other studies also have confirmed diversity's positive influence on coproduction. Using data on 1456 nonprofit board chief executive officers, Buse and colleagues found that both gender and racial diversity enhanced fundraising outcomes, which rely on donors' co-financing or donations. ${ }^{58}$ Another study found that more homogeneous Afro-descendant communities had lower public goods provisions. ${ }^{59}$

Proposition 3: Mission-related information affects coproduction positively.

Direct requests. As mentioned, public organizations can ask for citizens' help directly or nudge them without providing too many other types of information. ${ }^{60}$ For example, fundraising strategies can be as simple as 'Please help', which could help nonprofits increase donation revenues. ${ }^{61}$ People feel good when they are asked for help, because others need and respect them, and the power of asking has been documented well. For example, Andreoni and Rao used the 'dictator game' to test the power of asking experimentally. In this game, the dictator paired with a receiver to allocate a given endowment between the two. Compared with the baseline, in which no communication was allowed between them, allowing the receiver to ask increased allocation rates significantly from $15 \%$ to $24 \%$. This provides evidence that asking increases altruistic behavior, which is a form of coproduction. More strikingly, when two-way communication was permitted, $30 \%$ of the endowment was passed to the receiver. This high allocation rate is another piece of evidence of communications' positive effects on 
coproduction. ${ }^{62} \mathrm{Li}$ also found that 'Please help' and 'Thank you' messages increased willingness to donate significantly compared to no requests. ${ }^{63}$

Government initiatives, such as providing information and nudging strategies, can enhance coproduction in many ways. For example, governments that provide language-learning information to immigrant families encourage parents to coproduce their children's learning outcomes. ${ }^{64}$ Further, when governments request citizens' coproduction, it is more effective if they could incorporate nudging strategies or inform citizens about their expectations. ${ }^{65}$ Scholars used survey data from citizens in the UK, France, Germany, Denmark, and the Czech Republic and found some evidence that co-production is enhanced when governments provide information or engage citizens in consultation. ${ }^{66}$

Proposition 4: Direct requests have a positive effect on coproduction.

Financial information. When donors make a coproduction decision, they are interested not only in financial information, but nonfinancial information as well. ${ }^{67}$ However, empirical evidence tells varied stories about financial information's effects on individual coproduction decisions. For example, McDowell, Li, and Smith found that donors were more likely to gather nonfinancial information and integrate such information into giving decisions rather than obtain and use financial information. ${ }^{68}$ However, according to Saxton, Neely, and Guo's study, donors were more responsive and donated more when more financial information was available; however, they did not contribute more when additional nonfinancial information (performance or mission-related information) was available when the level of financial information disclosure was controlled. ${ }^{69}$

Different categorizations may explain these contradictory findings in part. According to Saxton and colleagues, financial information includes annual reports, audited financial statements, privacy policies, investment pool performance, policies and/or strategies, administrative costs, and IRS Form 990, while performance or mission-related information includes the organization's mission, a list and dollar amounts of recent grant awards, introduction of a community foundation, summaries of projects funded, program or grant effects, and grantee stories. However, McDowell et al. categorized nonprofit organizations' goals, outcomes, programs, and missions as nonfinancial information, and the program expense ratios and fundraising expense ratios as financial information. ${ }^{70}$

Proposition 5: Different pieces of financial information affect coproduction differently.

Performance information. There is no consensus on what constitutes performance information. Generally, performance information should be related to outcome measures and either the organizations themselves, such as government agencies, or other parties, such as an independent rating agency, may produce it. Thus, performance information includes data that performance monitoring, evaluating, and auditing systems generate. ${ }^{71}$ James and John used an example of government-produced performance information-the results of the Comprehensive Performance Assessment of local authorities in England-and showed that voters punished those electoral officials who performed poorly, but did not reward those who performed well. ${ }^{72}$ 
In the nonprofit world, watchdogs such as Charity Navigator, Foundation Center, and Guidestar (now merged into Candid), and the Better Business Bureau, all provide performance ratings for various charities. Li tested the effects of Charity Navigator 'stars' experimentally on individuals' willingness to donate and confirmed better performance ratings' (more stars) positive effects on donation intentions. ${ }^{73}$ However, better performance, such as that accumulated nonprofit wealth signals, does not always increase future donations and encourage future coproduction. ${ }^{74}$ Performance information is not as important to donors as expected, and many do not use rating information to inform their donation decisions. ${ }^{75}$

Proposition 6: Different pieces of performance information affect coproduction differently.

\section{Frequency and content}

Various amounts of the same information or the same frequency of different types of information influences individuals' coproduction decisions differently. More information does not necessarily lead to better performance, in that information overload has been found to be associated positively with decision makers' poorer performance. ${ }^{76}$ Further, communicating better performance information to citizens more frequently is unlikely to have the same influence on coproduction as communicating poor performance information more frequently. Thus, both frequency and information content influence coproduction. In this section, we discuss the way the frequency and content of mission-related, financial, and performance information, and direct requests influence coproduction.

Public and nonprofit organizations change their missions rarely, but they launch various programs and projects frequently that reflect their organizational missions and values. However, does more mission-related information increase coproduction? Li found that nonprofit organizations tweet mission-related information more frequently than the other three types of information, but such tweets do not translate into citizens' more positive attitudes toward these nonprofits. However, if the organizational mission is evaluated more highly, citizens are more willing to coproduce with the organization. $^{77}$ Further, long-term, high-frequency education about good values can increase coproduction. For example, a study found that longer secondary schooling, which educates students about democratic values frequently, mitigated anti-immigration attitudes later in life in five Western European countries-Denmark, France, Great Britain, Netherlands, and Sweden. ${ }^{78}$

Proposition 7: Higher frequencies of valued mission-related information affect coproduction positively.

Compared to no requests for citizens' cooperation, a direct request can increase it. Previous studies also have found that asking for a small donation increases the proportion of donors to nondonors without decreasing the donations' average amount. In addition, compared to unspecified requests for contributions, suggesting a specific, relatively small donation, such as five dollars, increases both the donation probability and amount. The content 'Even a penny will help' matters and its positive effects are 
documented well. ${ }^{79}$ However, more frequent requests do not necessarily result in further increases in coproduction. Li used tweets between nonprofit organizations and the public to test the relations between information frequency and the public's attitudes toward nonprofits and found that more direct requests are not associated with more positive attitudes toward these organizations. ${ }^{80}$ An Australian case study showed that a greater degree of interaction between practitioners and scholars can help enhance a coproduction partnership. ${ }^{81}$

Proposition 8: Requests for help are associated positively with coproduction, while more frequent requests are not.

Different pieces of financial information influence coproduction in various ways. For example, Trussel and Parsons found that such financial information as administrative efficiency, financial stability, fundraising effectiveness, and program revenues and grants, had positive effects on individual donations. ${ }^{82}$ In general, overhead ratios or administrative cost ratios are used to measure administrative efficiency. Lower overhead ratios mean higher administrative efficiency and increase donors' contributions further. ${ }^{83} \mathrm{Li}$ tested the positive and negative framing of the same overhead ratios experimentally, and confirmed the negative bias effect, in which donors penalize organizations with higher overhead ratios by reducing contributions or ceasing to donate. ${ }^{84}$ Further, government grants and funds to nonprofits either can crowd individual donations in or out. The mixed results of the 'crowding in/out' effects indicate that different donors process particular financial information, in this case, government funds, very differently. ${ }^{85}$

Does more financial information matter in individuals' coproduction decisions? Saxton and colleagues found that donors were more likely to cofinance social goods with nonprofit organizations when more financial information about them was available. $^{86}$ However, the authors did not specify the frequency and contents of financial information. In contrast, Li found no association between providing financial information more frequently and more positive public attitudes toward nonprofit organizations. $^{87}$

Proposition 9: Various financial information contents have heterogeneous effects on coproduction, and more financial information is not associated with more coproduction.

In general, if individuals use performance information to make their coproduction decisions, then they are more likely to coproduce with public organizations that perform better. A report by the Governmental Accounting Standards Board (GASB) citizen discussion groups on performance reporting showed that participants asked to use multiple information channels, from printed reports to online platforms, to the press and other media outlets, and to public forums, to communicate performance information with the public. The report also revealed that participants want more layers and details about performance. ${ }^{88}$

Again, the contents of performance information matter. When citizens use performance information, the numbers contained in the information could bias their attitudes toward public organizations and coproduction decisions. Olsen performed cognitive and social psychological studies of numbers' effects on human behavior to inform 
public administration scholars that we need to pay attention to the importance of numerical psychology when studying performance information. ${ }^{89}$ Moreover, lower government performance biases citizens negatively. ${ }^{90}$

However, the greatest challenge is that organizational managers and citizens use performance information rarely. ${ }^{91} \mathrm{Li}$ also confirmed that individuals penalize nonprofits with lower performance by reducing donations significantly and tweeting more frequently about performance information does not affect public attitudes toward organizations positively. ${ }^{92}$

Proposition 10: Citizens have a negative bias for poor performance information, and more performance information is not associated with more coproduction.

\section{Type I and Type II individuals}

The discussion above focused primarily on the effects on coproduction of communicating different types and contents of public organizational information through different channels to 'homogeneous' citizens at various frequencies. However, in the real world, citizens have diverse sociodemographic characteristics, as well as various incentives and information preferences, and thus, are not homogeneous. For example, financial rewards do not stimulate coproduction because a complex mixture of nonmonetary incentives motivates citizens. ${ }^{93}$ However, theoretical arguments and empirical evidence have suggested that higher levels of self-efficacy (perceived effects of individual coproduction efforts) predict a greater likelihood of coproduction. ${ }^{94}$ In addition, a study found that higher territorial motives (identifying with and claiming responsibility for space) were associated with a greater likelihood that an individual would coproduce community maintenance by reporting issues through the 311 system. ${ }^{95}$ Thus, examining the way heterogeneous incentives influence citizens' coproduction decisions should be an important task for future coproduction research.

This study, however, focused on individuals' heterogeneous information preferences and their implications for coproduction. The study does not discuss the relations between sociodemographic characteristics and information preferences. Generally, some people need more information than others when making coproduction decisions, and some have high information preferences while others have low information preferences. System 1 and System 2 might be responsible for these different information preferences. System 1 and System 2 is the metaphor Kahneman used to describe the two mental agents that produce fast (intuitive) and slow (deliberate) thinking respectively. In intuitive thinking, System 1 can make a fast decision without reference to more information, even when more information is available. On the other hand, in deliberate thinking, System 2 requires more information to make a more rational decision. ${ }^{96}$ It is reasonable to predict that some people rely more on System 1, while others rely more on System 2 when they are making decisions.

Li proposed two types of donors, in which Type I donors use System 1 and demand cheap information that can be processed intuitively without excessive cognitive effort, while Type II donors use System 2 and demand costly information that requires 
considerable cognitive effort to process. Further, Li categorized mission-related information and direct requests as cheap information and financial and performance information as costly information. Li suggested that nonprofit organizations should communicate strategically to satisfy different information needs to increase donations. $^{97}$

Building on Li's Type I and Type II donors, we extended these two types to all citizens, in which Type I individuals prefer cheap information to make intuitive decisions, while Type II individuals prefer costly information to make deliberate decisions. Then, the question becomes, how can public organizations communicate most effectively with different individuals with various information preferences, specifically, Type I and Type II individuals, to achieve better coproduction results?

Figure 3 illustrates the strategies with which public organizations communicate a specific piece of information to individuals. The model can be defined as (channels) . (frequencies) · (types) · (contents) · (Typel| Type II) $\rightarrow$ coproduction. To illustrate, we defined $(i)$ as a piece of a particular type of information. $p(C)$ is defined as the probability of choosing an information channel ' $C$ ' to communicate $(i)$, and $p(\bar{C})$ is defined as the probability of choosing an information channel ' $\bar{C}$ ' to communicate $(i)$. $f(I)$ and $f(I I)$ represent the frequencies of communicating such a piece of information through a particular channel to Type I and Type II individuals, respectively. We defined further that $f(I)+f(I I)=100 \%$ because of budget constraints.

We used three different strategies as an example. For example, (i) could be a direct request asking for help. If a public organization assumes that a direct request is not appealing to Type II individuals, who prefer costly information, the organization can achieve a pure strategy by reducing $f(I I)$ to zero (Strategy 1$)$. Similarly, if $(i)$ is a piece of financial information, the second strategy is to reduce $f(I)$ to zero (Strategy 2 ). In addition, there is a mixed strategy. If there are $\beta$ percentages of Type $I$ and $(1-\beta)$ Type II individuals in the population, then the organization could increase its communication efficiency and achieve better coproduction outcomes by communicating $\beta f(I)[p(i \mid C)+p(i \mid \bar{C})]$ to Type I and $(1-\beta) f(I I)[p(i \mid C)+p(i \mid \bar{C})]$ to Type II individuals, respectively (Strategy 3 ).

In summary, various channels, information types, frequencies, and contents have different effects on Type I and Type II individuals. Accordingly, we propose a set of hypotheses for future tests. We developed these hypotheses based on the 'relative'

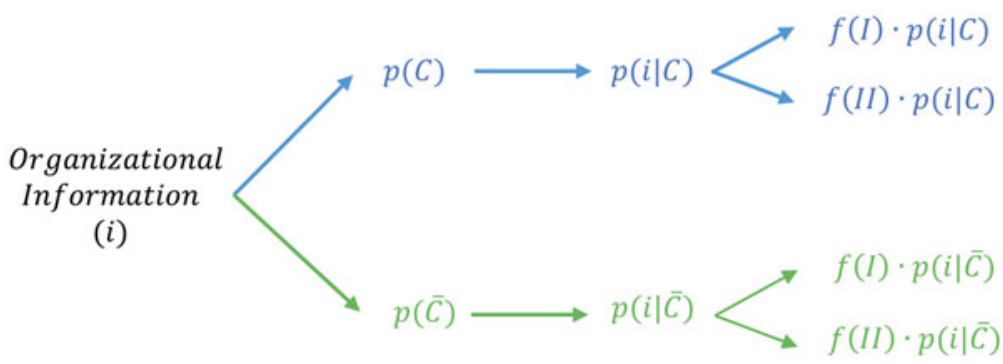

Figure 3. Organizational communication strategies for better coproduction. 
costs associated with each of the information channels, types, frequencies, and contents, and Type I and Type II individuals' different information preferences.

\begin{tabular}{|c|c|}
\hline \multicolumn{2}{|l|}{ Hypotheses of communication for coproduction } \\
\hline \multicolumn{2}{|l|}{ Information Channels } \\
\hline H1: Low cost channel & $\begin{array}{l}\text { Learning information by using ICT will have a greater } \\
\text { effect on Type I than Type II coproduction. }\end{array}$ \\
\hline H2: High cost channel & $\begin{array}{l}\text { Learning information from experience will have a } \\
\text { greater effect on Type II than Type I coproduction. }\end{array}$ \\
\hline \multicolumn{2}{|l|}{ Information Types } \\
\hline H3: Low cost mission-related information & $\begin{array}{l}\text { Mission-related information will have a greater effect } \\
\text { on Type I than Type II coproduction. }\end{array}$ \\
\hline H4: Low cost requests & $\begin{array}{l}\text { Direct requests will have a greater effect on Type I } \\
\text { than Type II coproduction. }\end{array}$ \\
\hline H5: High cost financial information & $\begin{array}{l}\text { Financial information will have a greater effect on Type } \\
\text { II than Type I coproduction. }\end{array}$ \\
\hline H6: High cost performance information & $\begin{array}{l}\text { Performance-related information will have a greater } \\
\text { effect on Type II than Type I coproduction. }\end{array}$ \\
\hline \multicolumn{2}{|l|}{ Information Frequencies and Contents } \\
\hline H7a: Relatively low cost mission-related information & $\begin{array}{l}\text { More pieces of positive mission-related information will } \\
\text { have a greater positive effect on Type I than on } \\
\text { Type II coproduction. }\end{array}$ \\
\hline H7b: Relatively low cost mission-related information & $\begin{array}{l}\text { More pieces of negative mission-related information } \\
\text { will have a greater negative effect on Type I than on } \\
\text { Type II coproduction. }\end{array}$ \\
\hline H8: Relatively low cost requests & $\begin{array}{l}\text { More direct requests for help will have a greater } \\
\text { positive effect on Type I than on Type II } \\
\text { coproduction. }\end{array}$ \\
\hline H9a: Relatively high cost financial information & $\begin{array}{l}\text { More pieces of good financial information will have a } \\
\text { greater positive effect on Type II than on Type I } \\
\text { coproduction. }\end{array}$ \\
\hline H9b: Relatively high cost financial information & $\begin{array}{l}\text { More pieces of poor financial information will have a } \\
\text { greater negative effect on Type II than on Type I } \\
\text { coproduction. }\end{array}$ \\
\hline H10a: Relatively high cost performance information & $\begin{array}{l}\text { More pieces of good performance information will have } \\
\text { a greater positive effect on Type II than on Type I } \\
\text { coproduction. }\end{array}$ \\
\hline H10b: Relatively high cost performance information & $\begin{array}{l}\text { More pieces of poor performance information will have } \\
\text { a greater negative effect on Type II than on Type I } \\
\text { coproduction. }\end{array}$ \\
\hline
\end{tabular}

\section{Conclusion and discussion}

In this study, we focused on communication, an issue overlooked often in the coproduction literature. The existing literature assumes that information between public organizations and citizens is symmetric and both parties understand each other during the coproduction process. However, we argue that there is an information asymmetry problem between public organizations and citizens that could prevent the latter from coproducing better policy outcomes and public goods with these organizations. Therefore, communicating effectively to reduce the degree of information asymmetry between public organizations and citizens both is theoretically and practically important.

We reviewed the literature systematically and highlighted the most relevant studies, discussed different information channels, types, frequencies, and contents' effects on coproduction, and summarized those effects in propositions. We conclude that using both ICT and online channels to obtain information and learning from personal 
experience increase citizen coproduction. With respect to different types of information, mission-related information affects coproduction positively and higher frequencies of valued mission-related information do so as well; further, direct requests for help are associated positively with coproduction, while more frequent requests are not; various financial information contents have heterogeneous effects on coproduction; neither more pieces of financial nor performance information is associated with more coproduction; and citizens have a negative bias for poor performance information.

Despite the influence of various channels, information types, frequencies, and contents on coproduction, we argued further that public organizations need to understand citizens' different information preferences to achieve effective communication that benefits coproduction. We introduced Type I and Type II individuals and argued that public organizations should communicate cheap information to Type I individuals, costly information to Type II individuals, or develop a mixed strategy to satisfy both types' information needs. Ideally, if public organizations can communicate cheap information (mission-related information and direct requests at low frequencies) to Type I individuals and costly information (financial and performance information at high frequencies) to Type II individuals, they can increase their communication efficiency and improve coproduction outcomes. We then proposed a set of hypotheses based on the 'relative' costs associated with each of the information channels, types, frequencies, and contents, and Type I and Type II individuals' different information preferences. We hope future empirical studies will test these hypotheses.

This study is not without limitations. For example, we did not discuss the factors that influence people's information preferences, which individuals' income level and educational background may alter. In addition, we did not discuss the effects of communications that include different information types. For example, organizations usually do not communicate only a piece of mission-related information to their stakeholders; instead, they communicate mission-related information together with other types of information. These aspects also demand more future studies.

The presented propositions and proposed hypotheses, if confirmed in the future, have practical implications. The positive effects of both online and offline information channels on coproduction suggest that public organizations and individuals should take advantage of the technology development to improve coproduction. There are many open-source collaborative computer and mobile phone applications that public organizations and citizens can use to achieve better communication. The promising effects on coproduction of learning from real experience suggest that more educational service-learning courses will benefit future coproduction. On the one hand, public organizations also should communicate frequently their values and mission-related information to the public if they want citizens to coproduce public good and services with them and not shy away from asking for citizens' help; on the other hand, they likely should focus less on communicating financial and performance information to citizens.

These practical implications, which are based on evidence from difference countries, also can be applied in China. The form of socialism in China does not mean that the Chinese Communist Party is responsible for providing all of the public goods and services and coproduction is unnecessary. Some public services universally require 
coproduction. For example, education inevitably is a coproduction process and education in China is no exception. We learned lessons about coproducing better educational outcomes from the systematic review and realized that government initiatives can play a positive role in motivating and nudging parents to coproduce, such as providing information and knowledge about the way to do so. In addition, the rapid growth in charitable foundations also exemplifies the necessity and improvement of coproduction in China. ${ }^{98}$

In addition, the Type I and Type II model implies that, unless they understand individuals' heterogeneous information preferences, public organizations may be unable to communicate with citizens effectively and thus, cannot improve coproduction. However, if public organizations consider individuals' different information preferences, they are more likely to be able to design more effective strategies to nudge citizens to coproduce.

In summary, we contribute to the literature by providing a systematic review and emphasizing the important roles communication and information play in coproduction. We hope the propositions and hypotheses presented in this study can serve as initial steps for future research on coproduction.

\section{Notes}

1. Brudney and England, "Toward a Definition of the Coproduction Concept," 59-65; Frederickson, "Toward a New Public Administration," 309-331; Riccucci and Van Ryzin, "Representative Bureaucracy," 21-30; Coleman et al., "Bureaucracy as a Representative Institution," 717-744.

2. Brudney and England, see note 1 above, 59 .

3. Jakobsen, "Can Government Initiatives Increase Citizen Coproduction," 27-54; Ostrom, "Crossing the Great Divide," 1073-1087; Parrado et al., "Correlates of Co-production," 85-112; Pestoff, "Citizens and Co-production of Welfare Services," 503-519; Riccucci et al., "Representative Bureaucracy in Policing," 537-551; Van Ryzin et al., "Representative Bureaucracy and Its Symbolic Effect on Citizens," 1365-1379.

4. Voorberg et al., "A Systematic Review of Co-Creation and Co-Production," 1333-1357.

5. Nabatchi et al., "Varieties of Participation in Public Services," 766-776; Voorberg et al., see note 4 above.

6. For a recent discussion, see Li, "Information and Donations," Chapter 2.

7. Frank and Salkever, "Nonprofit Organizations in the Health Sector," 129-144.

8. See note 6 above.

9. Graber, The Power of Communication, 193.

10. Kim et al., "A Systematic Review of Chinese Public Administration in English Language Journals (1996-2016)," 753-764; Kim et al., "Public Administration Research in Mainland China," 1-8; Moher et al., "Preferred Reporting Items for Systematic Reviews and MetaAnalyses," e1000097.

11. Li and Van Ryzin, "A Systematic Review of Experimental Studies in Public Management Journals," 20-36.

12. Brandsen and Honingh, "Distinguishing Different Types of Coproduction," 427-435; Brudney and England, see note 1 above; Ostrom, see note 3 above; Parks et al., "Consumers as Coproducers of Public Services," 1001-1011; Whitaker, "Coproduction," 240-246.

13. Cheng, "Exploring the Role of Nonprofits in Public Service Provision," 203-214; Sundeen, "Coproduction and Communities," 387-402.

14. Ferris, "Coprovision," 324-333; see note 6 above; Van Ryzin et al., see note 3 above. 
15. Ferris, see note 14 above.

16. Young, "Complementary, Supplementary, or Adversarial," 37-80.

17. Ferris, see note 14 above.

18. Warren, "Digital Member Network Implementation and Coproduction."

19. Meijer, "Networked Coproduction of Public Services in Virtual Communities," 598-607; Pestoff, see note 3 above; Voorberg et al., see note 4 above.

20. Riccucci et al., "Representative Bureaucracy and the Willingness to Coproduce," 121-130.

21. McDougle, et al., "Can Philanthropy be Taught," 330-351.

22. Ferris, "Coprovision," 324-333; See note 6 above.

23. Alford, "The Multiple Facets of Co-production," 299-316; Brandsen and Honingh, see note 12 above; Nabatchi et al., see note 5 above.

24. Nabatchi et al., see note 5 above.

25. Nabatchi et al., see note 5 above, 773 .

26. See note 4 above.

27. Gore, From Red Tape to Results, 46.

28. Maynard-Moody and Musheno, Cops, Teachers, and Counselors.

29. Clark, et al., "Coproduction of Government Services and the New Information Technology," 687-701; Pestoff, "Collective Action and the Sustainability of Co-Production," 383-401; Hand, "Producing a Vision of the Self-Governing Mother," 1148-1174.

30. Comfort, "Crisis Management in Hindsight," 189-197; Garnett et al., "Penetrating the Performance Predicament," 266-281; Pandey and Garnett, "Exploring Public Sector Communication Performance," 37-51.

31. See note 6 above; Rothschild and Stiglitz, "Equilibrium in Competitive Insurance Markets," 629-649.

32. Palumbo, "Contextualizing Co-production of Healthcare," 72-90.

33. Kettl, Little Bites of Big Data for Public Policy; Li, "Kettl, Little Bites of Big Data for Public Policy," 77-78.

34. Lasswell, "The Structure and Function of Communication in Society," 84.

35. See note 9 above; See note 6 above.

36. See note 34 above.

37. See note 6 above.

38. See note 9 above, 239.

39. Liu and Yuan, "The Evolution of Information and Communication Technology in Public Administration," 140-151.

40. Lember et al., "The Potential Impacts of Digital Technologies on Co-production and Cocreation," 1-22.

41. Meijer, see note 19 above.

42. Ingrams, "Mobile phones, Smartphones, and the Transformation of Civic Behavior through Mobile Information and Connectivity," 506-515.

43. Meijer, "New Media and the Coproduction of Safety," 17-34.

44. Li and McDougle, "Information Source Reliance and Charitable Giving Decisions," 549-560.

45. Li et al., "Philanthropy Can Be Learned," 29-52; McDougle et al., "Can Philanthropy Be Taught?" 330-351; Xu et al., "Experiential Philanthropy," 1-7.

46. Nesti, "Co-Production for Innovation," 310-325.

47. Buick et al., "Effective Practitioner-Scholar Relationships," 35-47.

48. Jakobsen, see note 3 above; Jakobsen and Andersen, "Coproduction and Equity in Public Service Delivery," 704-713.

49. Stevens and McGowan, Information Systems and Public Management, 16.

50. Hyndman, "Charity Accounting," 295-307.

51. McDowell, et al., "An Experimental Examination of US Individual Donors' Information Needs and Use," 327-347; Parsons, "Is Accounting Information from Nonprofit Organizations Useful to Donors," 104-129; Saxton et al., "Web Disclosure and the Market for Charitable Contributions," 127-144.

52. See note 6 above. 
53. Kim et al., "Experimental Research for Nonprofit Management," 415-436; See note 11 above.

54. See note 9 above, 3 .

55. Riccucci and Van Ryzin, see note 1 above.

56. See note 11 above; Riccucci et al., "Representative Bureaucracy, Race, and Policing," 506-518; Riccucci et al., see note 3 above; See note 20 above; Van Ryzin et al., see note 3 above.

57. See note 20 above.

58. Buse et al., "The Influence of Board Diversity, Board Diversity Policies and Practices, and Board Inclusion Behaviors on Nonprofit Governance Practices," 179-191.

59. Kustov and Pardelli, "Ethnoracial Homogeneity and Public Outcomes," 1096-1103.

60. Thaler and Sunstein, Nudge.

61. Andreoni and Rao, "The Power of Asking," 513-520; See note 6 above.

62. Andreoni and Rao, see note 61 above.

63. See note 6 above.

64. Andersen and Thomsen, "How to Increase Citizen Coproduction," 1-21; Jakobsen, see note 3 above; Jakobsen and Andersen, see note 48 above; Thomsen and Jakobsen, "Influencing Citizen Coproduction by Sending Encouragement and Advice," 286-303.

65. Mukherjee and Mukherjee, "Designing for Sustainable Outcomes," 326-346; Powers and Thompson, "Managing Coprovision," 179-196.

66. Parrado et al., see note 3 above.

67. Parsons, see note 51 above.

68. McDowell et al., see note 51 above.

69. Saxton et al., see note 51 above.

70. McDowell et al., see note 51 above; Saxton et al., see note 51 above.

71. Pollitt, "Performance Information for Democracy," 38-55.

72. James and John, "Public Management at the Ballot Box," 567-580.

73. See note 6 above.

74. Calabrese, "Do Donors Penalize Nonprofit Organizations with Accumulated Wealth," 859-869.

75. Cnaan et al., "Nonprofit Watchdogs," 381-397; Moxham et al., "Charities," 5-22.

76. O'reilly,Ill, "Individuals and Information Overload in Organizations," 684-696.

77. See note 6 above.

78. Cavaille and Marshall, "Education and Anti-Immigration Attitudes," 254-263.

79. Cialdini and Schroeder, "Increasing Compliance by Legitimizing Paltry Contributions," 599-604; Weyant and Smith, "Getting More by Asking for Less," 392-400.

80. See note 6 above.

81. See note 47 above.

82. Trussel and Parsons, "Financial Reporting Factors Affecting Donations to Charitable Organizations," 263-285.

83. Parsons and Trussel, "Fundamental Analysis of Not-for-profit Financial Statements," 216-218.

84. See note 6 above.

85. de Wit and Bekkers, "Government Support and Charitable Donations," 301-319; Lu, "The Philanthropic Consequence of Government Grants to Nonprofit Organizations," 381-400.

86. Saxton et al., see note 51 above.

87. See note 6 above.

88. Fountain et al., "Report on the GASB Citizen Discussion Groups on Performance Reporting."

89. Olsen, "The Numerical Psychology of Performance Information," 100-115.

90. James and Moseley, "Does Performance Information about Public Services Affect Citizens' Perception, Satisfaction, and Voice Behaviour," 493-511.

91. Moynihan and Pandey, "The Big Question for Performance Management," 849-866.

92. See note 6 above. 
93. Alford, "Why Do Public-Sector Clients Coproduce," 32-56; Voorberg et al., "Financial Rewards Do Not Stimulate Coproduction," 864-873.

94. Alonso et al., "Factors Influencing Citizens' Co-Production of Environmental Outcomes," 1-26; Bovaird et al., "Activating Collective Co-Production of Public Services," 47-68; Thomsen, "Citizen Coproduction," 340-353; Van Eijk and Steen, "Why Engage in CoProduction of Public Services?," 28-46.

95. O'Brien et al., "Uncharted Territoriality in Coproduction," 320-335.

96. Kahneman, Think, Fast and Slow.

97. See note 6 above.

98. Li and Chen, "Turning Challenges into Opportunities: Advancing Studies of Nonprofit Organizations in China," 1-5; Ma et al., "The Research Infrastructure of Chinese Foundations, a Database for Chinese Civil Society Studies," 170094.

\section{Acknowledgments}

I thank Jeffery Brudney, Chao Guo, Yondong Shen, and participants of the 2018 Coproduction Workshop at Zhejiang University for helpful comments. All remaining errors are my own.

\section{Disclosure statement}

No potential conflict of interest was reported by the author.

\section{Notes on contributor}

Huafang $\mathrm{Li}$ is an assistant professor in the School of Public, Nonprofit and Health Administration at Grand Valley State University. He uses mixed methods to study how citizens react to information about public policies and organizations.

\section{References}

Alford, John. "The Multiple Facets of Co-Production: Building on the Work of Elinor Ostrom." Public Management Review 16, no. 3 (2014): 299-316. doi:10.1080/14719037.2013.806578.

Alford, John. "Why Do Public-Sector Clients Coproduce? Toward a Contingency Theory." Administration \& Society 34, no. 1 (2002): 32-56. doi:10.1177/0095399702034001004.

Alonso, José M., Rhys Andrews, Judith Clifton, and Daniel Diaz-Fuentes. "Factors Influencing Citizens' Co-Production of Environmental Outcomes: A Multi-Level Analysis." Public Management Review (2019). doi:10.1080/147190372019.1619806.

Andersen, Simon Calmar, Helena Skyt Nielsen, and Mette Kjaergaard Thomsen. "How to Increase Citizen Coproduction: Replication and Extension of Existing Research." International Public Management Journal (2018): 1-21. doi:10.1080/10967494.2018.1518851.

Andreoni, James, and Justin M. Rao. "The Power of Asking: How Communication Affects Selfishness, Empathy, and Altruism." Journal of Public Economics 95, no. 7-8 (2011): 513-520. doi:10.1016/j.jpubeco.2010.12.008.

Bovaird, Tony, Gerry Stoker, Tricia Jones, Elke Loeffler, and Monica Pinilla Roncancio. "Activating Collective Co-Production of Public Services: Influencing Citizens to Participate in Complex Governance Mechanisms in the UK." International Review of Administrative Sciences 82, no. 1 (2016): 47-68. doi:10.1177/0020852314566009.

Brandsen, Taco, and Marlies Honingh. "Distinguishing Different Types of Coproduction: A Conceptual Analysis Based on the Classical Definitions." Public Administration Review 76, no. 3 (2016): 427-435. doi:10.1111/puar.12465.

Brudney, Jeffrey, and Robert E. England. "Toward a Definition of the Coproduction Concept." Public Administration Review 43, no. 1 (1983): 59-65. doi:10.2307/975300. 
Buick, Fiona, Deborah Blackman, Janine O'Flynn, Michael O'Donnell, and Damian West. "Effective Practitioner-Scholar Relationships: Lessons from a Coproduction Partnership." Public Administration Review 76, no. 1 (2016): 35-47. doi:10.1111/puar.12481.

Buse, Kathleen, Ruth Sessler Bernstein, and Diana Bilimoria. "The Influence of Board Diversity, Board Diversity Policies and Practices, and Board Inclusion Behaviors on Nonprofit Governance Practices." Journal of Business Ethics 133, no. 1 (2016): 179-191. doi:10.1007/ s10551-014-2352-z.

Calabrese, Thad D. "Do Donors Penalize Nonprofit Organizations with Accumulated Wealth?" Public Administration Review 71, no. 6 (2011): 859-869. doi:10.1111/j.1540-6210.2011.02420.x.

Cavaille, Charlotte, and John Marshall. "Education and anti-Immigration Attitudes: Evidence from Compulsory Schooling Reforms across Western Europe." American Political Science Review 113, no. 1 (2019): 254-263. doi:10.1017/S0003055418000588.

Cheng, Yuan (Daniel). "Exploring the Role of Nonprofits in Public Service Provision: Moving from Coproduction to Cogovernance." Public Administration Review 79, no. 2 (2019): 203-214. doi: 10.1111/puar.12970.

Cialdini, Robert B., and David A. Schroeder. "Increasing Compliance by Legitimizing Paltry Contributions: When Even a Penny Helps." Journal of Personality and Social Psychology 34, no. 4 (1976): 599-604. doi:10.1037/0022-3514.34.4.599.

Clark, Benjamin Y., Jeffrey L. Brudney, and Sung-Gheel Jang. "Coproduction of Government Services and the New Information Technology: Investigating the Distributional Biases." Public Administration Review 73, no. 5 (2013): 687-701. doi:10.1111/puar.12092.

Cnaan, Ram A., Kathleen Jones, Allison Dickin, and Michele Salomon. "Nonprofit Watchdogs: Do They Serve the Average Donor." Nonprofit Management and Leadership 21, no. 4 (2011): 381-397. doi:10.1002/nml.20032.

Coleman, Sally, Jeffrey L. Brudney, and J. Edward Kellough. "Bureaucracy as a Representative Institution: Toward a Reconciliation of Bureaucratic Government and Democratic Theory." American Journal of Political Science 42, no. 3 (1998): 717-744. doi:10.2307/2991727.

Comfort, Louise K. "Crisis Management in Hindsight: Cognition, Communication, Coordination, and Control." Public Administration Review 67, no. s1 (2007): 189-197. doi:10.1111/j.1540-6210. 2007.00827.x.

Ferris, James M. "Coprovision: Citizen Time and Money Donations in Public Service Provision." Public Administration Review 44, no. 4 (1984): 324-333. doi:10.2307/976078.

Fountain, James, Wilson Campbell, Paul Epstein, and Brett Robinson. "Report on the GASB Citizen Discussion Groups on Performance Reporting." GASB Reserch Reports. Norwalk, CT: Governmental Accounting Standards Board of the Financial Accounting Foundation, 2002. Accessed Nov 20, 2019. http://www.seagov.org/sea_gasb_project/reports_citizen.pdf.

Frank, Richard G., and David S. Salkever. "Nonprofit Organizations in the Health Sector." Journal of Economic Perspectives 8, no. 4 (1994): 129-144. doi:10.1257/jep.8.4.129.

Frederickson, George H. "Toward a New Public Administration." In Toward a New Public Administration: The Minnowbrook Perspective, edited by Frank Marini, 309-331. San Francisco, CA: Chandler Publishing Company, 1971.

Garnett, James L., Justin Marlowe, and Sanjay K. Pandey. "Penetrating the Performance Predicament: Communication as a Mediator or Moderator of Organizational Culture's Impact on Public Organizational Performance." Public Administration Review 68, no. 2 (2008): 266-281. doi:10.1111/j.1540-6210.2007.00861.x.

Gore, Al. From Red Tape to Results: Creating A Government That Works Better \& Costs Less. Report of the National Performance Review. Washington, DC: Government Pringint Office, 1993. https://eric.ed.gov/?id=ED384294.

Graber, Doris A. The Power of Communication: Managing Information in Public Organizations. Washington, DC: CQ Press, 2003.

Hand, Laura C. "Producing a Vision of the Self-Governing Mother: A Study of Street-Level Bureaucrat Behavior in Coproductive Interactions." Administration \& Society 50, no. 8 (2018): 1148-1174. doi:10.1177/0095399717719110. 
Hyndman, Noel. "Charity Accounting-an Empirical Study of the Information Needs of Contributors to UK Fund Raising Charities." Financial Accountability and Management 6, no. 4 (1990): 295-307. doi:10.1111/j.1468-0408.1990.tb00335.x.

Ingrams, Alex. "Mobile Phones, Smartphones, and the Transformation of Civic Behavior through Mobile Information and Connectivity." Government Information Quarterly 32, no. 4 (2015): 506-515. doi:10.1016/j.giq.2015.07.007.

Jakobsen, Morten, and Simon Calmar Andersen. "Coproduction and Equity in Public Service Delivery." Public Administration Review 73, no. 5 (2013): 704-713. doi:10.1111/puar.12094.

Jakobsen, Morten. "Can Government Initiatives Increase Citizen Coproduction? Results of a Randomized Field Experiment." Journal of Public Administration Research and Theory 23, no. 1 (2013): 27-54. doi:10.1093/jopart/mus036.

James, Oliver, and Alice Moseley. "Does Performance Information about Public Services Affect Citizens' Perception, Satisfaction, and Voice Behaviour? Field Experiments with Absolute and Relative Performance Information." Public Administration 92, no. 2 (2014): 493-511. doi:10. $1111 /$ padm. 12066.

James, Oliver, and Peter John. "Public Management at the Ballot Box: Performance Information and Electoral Support for Incumbent English Local Governments." Journal of Public Administration Research and Theory 17, no. 4 (2006): 567-580. doi:10.1093/jopart/mul020.

Kahneman, Daniel. Thinking, Fast and Slow. New York City, NY: Farrar, Straus and Giroux, 2013. Kettl, Donald F. Little Bites of Big Data for Public Policy. Washington, DC: CQ Press, 2018.

Kim, Min-Hyu, Huafang Li, Marc Holzer, and Mengzhong Zhang. "Public Administration Research in Mainland China." In Global Encyclopedia of Public Administration, Public Policy, and Governance, edited by Ali Farazmand. Cham, Switzerland: Springer International Publishing, 2019. doi:10.1007/978-3-319-31816-5_3717-1.

Kim, Min-Hyu, Huafang Li, Marc Holzer, and Mengzhong Zhang. "Public Administration Research in Mainland China: A Systematic Review of Chinese Public Administration in English Language Journals (1996-2016)." International Journal of Public Administration 49, no. 2 (2019): 753-764. doi:10.1080/01900692.2018.1506936.

Kim, Mirae, Dyana P. Mason, and Huafang Li. "Experimental Research for Nonprofit Management: Charitable Giving and Fundraising." In Experiments in Public Management Research: Challenges \& Contributions, edited by Oliver James, Sebastian Jilke, and GREGG G Van Ryzin, 415-436. Cambridge, UK: Cambridge University Press, 2017.

Kustov, Alexander, and Giuliana Pardelli. "Ethnoracial Homogeneity and Public Outcomes: The (Non)Effects of Diversity." American Political Science Review 112, no. 4 (2018): 1096-1103. doi: $10.1017 /$ S0003055418000308.

Lasswell, Harold D. "The Structure and Function of Communication in Society." In Mass Communications, edited by Wilbur Schramm and Donald Roberts, 84. Urbana, IL: University of Illinois Press, 1971.

Lember, Veiko, Taco Brandsen, and Piret Tõnurist. "The Potential Impacts of Digital Technologies on Co-Production and Co-Creation." Public Management Review 21, no. 11 (2019): 1665. doi: 10.1080/14719037.2019.1619807.

$\mathrm{Li}$, Huafang, and Bin Chen. "Turning Challenges into Opportunities: Advancing Studies of Nonprofit Organizations in China." Chinese Public Administration Review 9, no. 1 (2018): 1-5. doi:10.22140/cpar.v9i1.172.

Li, Huafang, Gregg G. Van Ryzin. "A Systematic Review of Experimental Studies in Public Management Journals." In Experiments in Public Management Research: Challenges \& Contributions, edited by Oliver James, Sebastian Jilke, and Gregg G. Van Ryzin, 20-36. Cambridge, UK: Cambridge University Press, 2017. doi:10.1017/9781316676912.003.

$\mathrm{Li}$, Huafang, and Lindsey McDougle. "Information Source Reliance and Charitable Giving Decisions." Nonprofit Management and Leadership 27, no. 4 (2017): 549-560. doi:10.1002/nml. 21258.

Li, Huafang, Chengxin Xu, and Lindsey McDougle. "Philanthropy Can Be Learned: A Qualitative Study of Student Experiences in Experiential Philanthropy Courses." Philosophy \& Education 2, no. 2 (2019): 29-52. doi:10.2979/phileduc.2.2.02. 
Li, Huafang. "Donald Kettl, Little Bites of Big Data for Public Policy." Chinese Public Administration Review 10, no. 1 (2019): 77-78. doi:10.22140/cpar.v10i1.194.

$\mathrm{Li}$, Huafang. "Information and Donations: A Study of Nonprofit Online Communication." Dissertation, Rutgers University, 2017. doi:10.7282/T35T3PDQ.

Liu, Shuhua Monica, and Qianli Yuan. "The Evolution of Information and Communication Technology in Public Administration." Public Administration and Development 35, no. 2 (2015): 140-151. doi:10.1002/pad.1717.

Lu, Jiahuan. "The Philanthropic Consequence of Government Grants to Nonprofit Organizations: A Meta-Analysis." Nonprofit Management and Leadership 26, no. 4 (2016): 381-400. doi:10. $1002 / \mathrm{nml} .21203$.

$\mathrm{Ma}$, Ji, Qun Wang, Chao Dong, and Huafang Li. "The Research Infrastructure of Chinese Foundations, a Database for Chinese Civil Society Studies." Scientific Data 4, no. 1 (2017): 170094. doi:10.1038/sdata.2017.94.

Maynard-Moody, Steven, and Michael Craig Musheno. Cops, Teachers, Counselors: Stories from the Front Lines of Public Service. Ann Arbor, MI: University of Michigan Press, 2009.

McDougle, Lindsey, Danielle McDonald, Huafang Li, Whitney McIntyre Miller, and Chengxin Xu. "Can Philanthropy Be Taught?" Nonprofit and Voluntary Sector Quarterly 46, no. 2 (2017): 330-351. doi:10.1177/0899764016662355.

McDowell, Evelyn A., Wei Li, and Pamela C. Smith. "An Experimental Examination of US Individual Donors' Information Needs and Use." Financial Accountability \& Management 29, no. 3 (2013): 327-347. doi:10.1111/faam.12017.

Meijer, Albert J. "Networked Coproduction of Public Services in Virtual Communities: From a Government-Centric to a Community Approach to Public Service Support." Public Administration Review 71, no. 4 (2011): 598-607. doi:10.1111/j.1540-6210.2011.02391.x.

Meijer, Albert J. "New Media and the Coproduction of Safety: An Empirical Analysis of Dutch Practices." The American Review of Public Administration 44, no. 1 (2014): 17-34. doi:10.1177/ 0275074012455843.

Moher, David, Alessandro Liberati, Jennifer Tetzlaff, and Douglas G. Altman. "Preferred Reporting Items for Systematic Reviews and Meta-Analyses: The PRISMA Statement." PLoS Medicine 6, no. 7 (2009): e1000097. doi:10.1371/journal.pmed.1000097.

Moxham, Claire, Ton van der Wiele, Roger Williams, and Jos van Iwaarden. "Charities: How Important is Performance to Donors?" International Journal of Quality \& Reliability Management 26, no. 1 (2009): 5-22. doi:10.1108/02656710910924143.

Moynihan, Donald P., and Sanjay K. Pandey. "The Big Question for Performance Management: Why Do Managers Use Performance Information?" Journal of Public Administration Research and Theory 20, no. 4 (2010): 849-866. doi:10.1093/jopart/muq004.

Mukherjee, Ishani, and Nilanjana Mukherjee. "Designing for Sustainable Outcomes: Espousing Behavioural Change into Co-Production Programmes." Policy and Society 37, no. 3 (2018): 326-346. doi:10.1080/14494035.2018.1383032.

Nabatchi, Tina, Alessandro Sancino, and Mariafrancesca Sicilia. "Varieties of Participation in Public Services: The Who, When, and What of Coproduction." Public Administration Review 77, no. 5 (2017): 766-776. doi:10.1111/puar.12765.

Nesti, Giorgia. "Co-Production for Innovation: The Urban Living Lab Experience." Policy and Society 37, no. 3 (2018): 310-325. doi:10.1080/14494035.2017.1374692.

O'Brien, Daniel Tumminelli, Dietmar Offenhuber, Jessica Baldwin-Philippi, Melissa Sands, and Eric Gordon. "Uncharted Territoriality in Coproduction: The Motivations for 311 Reporting." Journal of Public Administration Research and Theory 27, no. 2 (2017): 320-335. doi:10.1093/jopart/ muw046.

O'Reilly, Charles A. "Individuals and Information Overload in Organizations: Is More Necessarily Better?" Academy of Management Journal 23, no. 4 (1980): 684-696. doi:10.5465/255556.

Olsen, Asmus Leth. "The Numerical Psychology of Performance Information: Implications for Citizens, Managers, and Policymakers." Public Performance \& Management Review 39, no. 1 (2015): 100-115. doi:10.1080/15309576.2016.1071167. 
Ostrom, Elinor. "Crossing the Great Divide: Coproduction, Synergy, and Development." World Development 24, no. 6 (1996): 1073-1087. doi:10.1016/0305-750X(96)00023-X.

Palumbo, Rocco. "Contextualizing Co-Production of Health Care: A Systematic Literature Review." International Journal of Public Sector Management 29, no. 1 (2016): 72-90. doi:10.1108/JJPSM07-2015-0125.

Pandey, Sanjay K., and James L. Garnett. "Exploring Public Sector Communication Performance: Testing a Model and Drawing Implications." Public Administration Review 66, no. 1 (2006): 37-51. doi:10.1111/j.1540-6210.2006.00554.x.

Parks, Roger B., Paula C. Baker, Larry Kiser, Ronald Oakerson, Elinor Ostrom, Vincent Ostrom, Stephen L. Percy, Martha B. Vandivort, Gordon P. Whitaker, and Rick Wilson. "Consumers as Coproducers of Public Services: Some Economic and Institutional Considerations." Policy Studies Journal 9, no. 7 (1981): 1001-1011. doi:10.1111/j.1541-0072.1981.tb01208.x.

Parrado, Salvador, Gregg G. Van Ryzin, Tony Bovaird, and Elke LÖffler. "Correlates of CoProduction: Evidence from a Five-Nation Survey of Citizens." International Public Management Journal 16, no. 1 (2013): 85-112. doi:10.1080/10967494.2013.796260.

Parsons, Linda M. "Is Accounting Information from Nonprofit Organizations Useful to Donors? A Review of Charitable Giving and Value-Relevance." Journal of Accounting Literature 22, no. 1 (2003): 104-129.

Parsons, Linda M., and John M. Trussel. "Fundamental Analysis of Not-for-Profit Financial Statements: An Examination of Financial Vulnerability Measure." Research in Governmental and Nonprofit Accounting 12, (2008): 216-218.

Pestoff, Victor. "Citizens and Co-Production of Welfare Services: Childcare in Eight European Countries." Public Management Review 8, no. 4 (2006): 503-519. doi:10.1080/ 14719030601022882.

Pestoff, Victor. "Collective Action and the Sustainability of Co-Production." Public Management Review 16, no. 3 (2014): 383-401. doi:10.1080/14719037.2013.841460.

Pollitt, Christopher. "Performance Information for Democracy: The Missing Link?" Evaluation 12, no. 1 (2006): 38-55. doi:10.1177/1356389006064191.

Powers, Kathleen J., and Fred Thompson. "Managing Coprovision: Using Expectancy Theory to Overcome the Free-Rider Problem." Journal of Public Administration Research and Theory 4, no. 2 (1994): 179-196. doi:10.1093/oxfordjournals.jpart.a037203.

Riccucci, Norma M., Gregg G. Van Ryzin, and Karima Jackson. "Representative Bureaucracy, Race, and Policing: A Survey Experiment." Journal of Public Administration Research and Theory 28, no. 4 (2018): 506-518. doi:10.1093/jopart/muy023.

Riccucci, Norma M., Gregg G. Van Ryzin, and Huafang Li. "Representative Bureaucracy and the Willingness to Coproduce: An Experimental Study." Public Administration Review 76, no. 1 (2016): 121-130. doi:10.1111/puar.12401.

Riccucci, Norma M., and Gregg G. Van Ryzin. "Representative Bureaucracy: A Lever to Enhance Social Equity, Coproduction, and Democracy." Public Administration Review 77, no. 1 (2017): 21-30. doi:10.1111/puar.12649.

Riccucci, Norma M., Gregg G. Van Ryzin, and Cecilia F. Lavena. "Representative Bureaucracy in Policing: Does It Increase Perceived Legitimacy?" Journal of Public Administration Research and Theory 24, no. 3 (2014): 537-551. doi:10.1093/jopart/muu006.

Rothschild, Michael, and Joseph Stiglitz. "Equilibrium in Competitive Insurance Markets: An Essay on the Economics of Imperfect Information." The Quarterly Journal of Economics 90, no. 4 (1976): 629-649. doi:10.2307/1885326.

Saxton, Gregory, Daniel Neely, and Chao Guo. "Web Disclosure and the Market for Charitable Contributions." Journal of Accounting and Public Policy 33, no. 2 (2014): 127-144. doi:10.1016/ j.jaccpubpol.2013.12.003.

Stevens, John, and Robert McGowan. Information Systems and Public Management. New York, NY: Praeger Publishers, 1985.

Sundeen, Richard A. "Coproduction and Communities: Implications for Local Administrators." Administration \& Society 16, no. 4 (1985): 387-402. doi:10.1177/009539978501600401. 
Thaler, Richard H., and Cass R. Sunstein. Nudge: Improving Decisions about Health, Wealth and Happiness. New Haven, CT: Yale University Press, 2008.

Thomsen, Mette Kjaergaard, and Morten Jakobsen. "Influencing Citizen Coproduction by Sending Encouragement and Advice: A Field Experiment." International Public Management Journal 18, no. 2 (2015): 286-303. doi:10.1080/10967494.2014.996628.

Thomsen, Mette K. "Citizen Coproduction: The Influence of Self-Efficacy Perception and Knowledge of How to Coproduce." American Review of Public Administration 47, no. 3 (2017): 340-353. doi:10.1177/0275074015611744

Trussel, John M., and Linda M. Parsons. "Financial Reporting Factors Affecting Donations to Charitable Organizations." Advances in Accounting 23, (2007): 263-285. doi:10.1016/S08826110(07)23010-X.

Van Eijk, Carola, and Trui Steen. "Why Engage in Co-Production of Public Services? Mixing Theory and Empirical Evidence." International Review of Administrative Sciences 82, no. 1 (2016): 28-46. doi:10.1177/0020852314566007.

Van Ryzin, Gregg, Norma Riccucci, and Huafang Li. "Representative Bureaucracy and Its Symbolic Effect on Citizens: A Conceptual Replication." Public Management Review 19, no. 9 (2017): 1365-1379. doi:10.1080/14719037.2016.1195009.

Voorberg, William, Sebastian Jilke, Lars Tummers, and Victor Bekkers. "Financial Rewards Do Not Stimulate Coproduction: Evidence from Two Experiments." Public Administration Review 78, no. 6 (2018): 864-873. doi:10.1111/puar.12896.

Voorberg, William H., Victor J. J. M. Bekkers, and Lars G. Tummers. "A Systematic Review of CoCreation and Co-Production: Embarking on the Social Innovation Journey." Public Management Review 17, no. 9 (2015): 1333-1357. doi:10.1080/14719037.2014.930505.

Warren, Derrick. "Digital Member Network Implementation and Coproduction: An Investigation of an Alumni Association Network." Dissertation, Georgia State University, 2019. https://scholarworks.gsu.edu/bus_admin_diss/119.

Weyant, James M., and Stephen L. Smith. "Getting More by Asking for Less: The Effects of Request Size on Donations of Charity1." Journal of Applied Social Psychology 17, no. 4 (1987): 392-400. doi:10.1111/j.1559-1816.1987.tb00320.x.

Whitaker, Gordon. "Coproduction: Citizen Participation in Service Delivery." Public Administration Review 40, no. 3 (1980): 240-246. doi:10.2307/975377.

Wit, Arjen de., and René Bekkers. "Government Support and Charitable Donations: A MetaAnalysis of the Crowding-out Hypothesis." Journal of Public Administration Research and Theory 27, no. 2 (2017): 301-319. doi:10.1093/jopart/muw044.

$\mathrm{Xu}$, Chengxin, Huafang Li, and Lindsey M. McDougle. "Experiential Philanthropy." In Global Encyclopedia of Public Administration, Public Policy, and Governance, 1-7. Cham, Switzerland: Springer International Publishing, 2018. doi:10.1007/978-3-319-31816-5_3048-1.

Young, Dennis R. "Complementary, Supplementary, or Adversarial? Nonprofit-Government Relations." In Nonprofits and Government: Collaboration and Conflict, 2nd ed. edited by Elizabeth T. Boris and C. Eugene Steuerle, 37-80. Washington, DC: The Urban Institute Press, 2006. 


\section{Appendix}

Google Scholar Top 20 Public Policy and Administration Journals.

\begin{tabular}{llll}
\hline & \multicolumn{1}{c}{ Publication } & h5-index & h5-median \\
\hline 1 & Public Administration Review & 51 & 77 \\
2 & Journal of Public Administration Research and Theory & 44 & 73 \\
3 & Public Management Review & 41 & 66 \\
4 & Public Administration & 38 & 52 \\
5 & Governance & 35 & 50 \\
6 & Policy Studies Journal & 32 & 58 \\
7 & Environment and Planning C: Government and Policy & 32 & 45 \\
8 & The American Review of Public Administration & 31 & 38 \\
9 & Policy \& Politics & 26 & 43 \\
10 & Science and Public Policy & 26 & 36 \\
11 & Administration \& Society & 25 & 43 \\
12 & International Review of Administrative Sciences & 25 & 36 \\
13 & Local Government Studies & 24 & 37 \\
14 & Policy Sciences & 23 & 41 \\
15 & Review of Public Personnel Administration & 23 & 37 \\
16 & Social Policy \& Administration & 23 & 35 \\
17 & Review of Policy Research & 22 & 35 \\
18 & Transforming Government: People, Process and Policy & 22 & 35 \\
19 & International Public Management Journal & 21 & 32 \\
20 & Policy and Society & 21 & 28 \\
\hline
\end{tabular}

The ranking is based on Google Scholar's May 2019 data. Google Scholar only ranks the top 20 journals based on the h5-index, which underestimates journals with low h5-index scores. 